\title{
Evaluation of the working life quality as a part of the human resources management system of a modern enterprise
}

\author{
$O$. Frolova ${ }^{1}, A$. Kopytova $^{1, *}$, and $E$. Matys ${ }^{1}$ \\ ${ }^{1}$ Industrial university of Tyumen, Volodarskogo str. 38, Tyumen, 625001, Russia
}

\begin{abstract}
The article is devoted to the problem of evaluation of the working life quality of personnel of a modern Russian enterprise. On the basis of a survey of employees of enterprises in various spheres of activity in the Tyumen region using a full (dispensing) questionnaire, satisfactory and unsatisfactory criteria characterizing the quality of their working life are revealed. The research shows that within the framework of the motivational system, the provision of employees of the Tyumen region enterprises with social benefits ranks last, while the state's social policy is aimed at raising this indicator, at material and physical well-being, and at social and legal protection of the person. Social benefits and social guarantees form an important sphere of working life and contribute to a significant improvement in the quality of working life. Satisfaction with the work activity is formed under the influence of a large number of factors. Detailed study and analysis of each factor will improve the quality of working life of employees of the Tyumen region enterprises. The conducted research confirms that there are no violations in the sphere of legislative provision with social guarantees at the enterprises of the Tyumen region. This means that the payment of sick leave sheets and payments provided in the Labor Code of the Russian Federation are fully implemented without violating the deadlines. In addition, the civil rights of employees are respected and leave is granted in accordance with the schedule. On the basis of the study, the authors proposed ways to improve the quality of working life of employees in the Tyumen region.
\end{abstract}

\section{Introduction}

Effective management of the enterprise, industry, region and the state as a whole assumes a whole system of interrelated elements. One of the components that underlies management of the life quality is the evaluation of the quality of work life in individual enterprises. The quality of working life is an integral part of the human resource management system. It is the quality of working life and its increase that contributes to the growth of enterprise productivity.

The legislation of the Russian Federation [1,2,3] is aimed at protecting the social interests of citizens and the growth of indicators of satisfaction with the quality of working

\footnotetext{
${ }^{*}$ Corresponding author: a.copytowa@yandex.ru
} 
life and the quality of life of the population as a whole.

Many scientists were engaged in studying the problems of effective management of human resources in general and the quality of working life in the Russian Federation: Egorshin A.P., Kibanov A.Ya., Ryabokon I.A., Trapitsin S.Y., Gerasimov B.I. and others $[4,8,9,16-28]$. They investigated the management of human resources as a system in general, various motivational aspects, indicators of the quality of working life, staff assessments and other issues.

The indicators of the quality of working life, taking into account the time aspect, have the property of changing. In addition, these indicators have a huge impact on the economy of the country as a whole and the current legislation.

\section{Methods}

During the research, the authors used the following methods: theoretical analysis and generalization of scientific literature and legislative acts of the Russian Federation; questioning.

The evaluation of the quality of working life can be carried out using the questionnaire proposed by A. Egorshin [8,9], which was developed taking into account the survey of more than 200 scientists and leaders. As a result, it was found that the quality of working life is affected by the indicators shown in Figure 1.

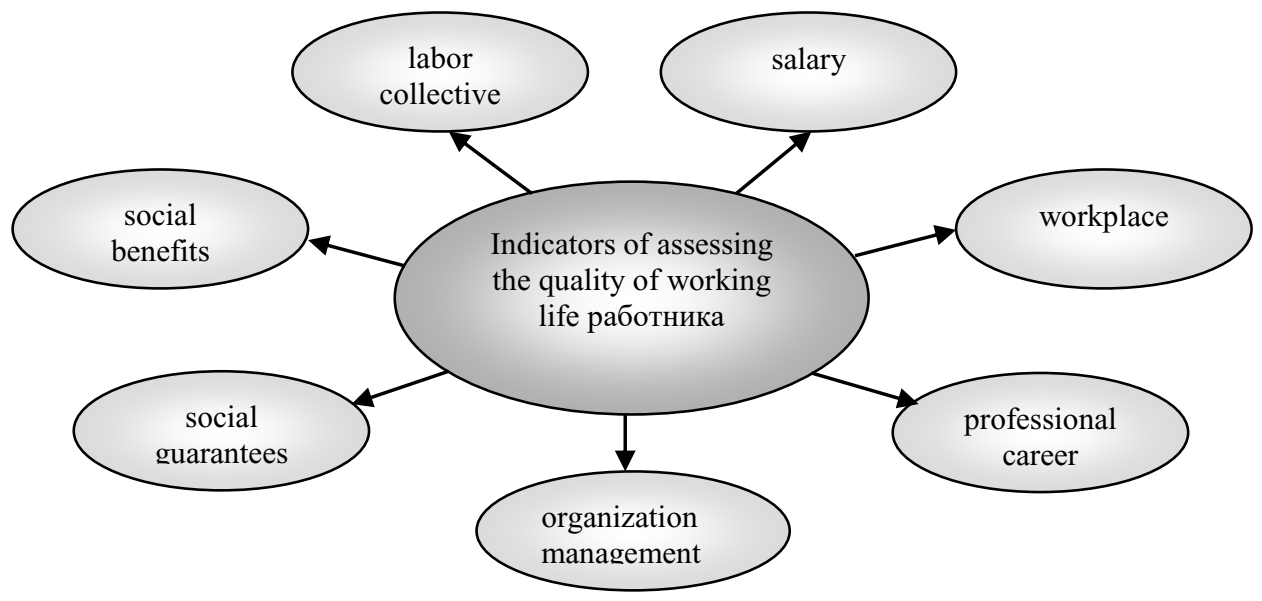

Fig. 1. Indicators of the assessment of the quality of working life of an employee.

This technique is aimed at the subjective perception of the working conditions, opportunities for career growth, position in the organization, provided social benefits and guarantees by the employee. The evaluation is carried out using questionnaires suggesting seven main sections (each section is estimated by ten indicators) on a ten-point scale (10 the maximum value of the indicator, 1 - the minimum). The result is the calculation of the score for each section (group of indicators) for each employee.

The scoring scale of the indicators of the questionnaire "quality of working life":

Up to 49 points - unsatisfactory;

50 to 69 points - satisfactory;

70 to 89 points - good;

More than 90 points - excellent.

The total score for 7 sections:

Up to 349 points - unsatisfactory; 
350 to 489 points - satisfactory;

490 to 629 points - it's good;

More than 630 points - excellent.

\section{Results}

In order to diagnose the indicators of the quality of working life at the enterprises of the Tyumen region, a sociological survey was conducted on the basis of a sample survey, the sample of which was 508 workers of various categories (managers, specialists, workers). The survey was conducted at 50 enterprises of the Tyumen region in various fields of activity (trade, transport, construction, communications, heat and power engineering, housing and communal services, municipal institutions, etc.).

To obtain objective results for the Tyumen region, the average values for each of the 7 groups of indicators and the average value for enterprises as a whole were calculated.

The result of the questionnaire was identified negative factors affecting the quality of working life of workers in the enterprises of the Tyumen region.

The results of processing the questionnaires are shown in Figure 2.

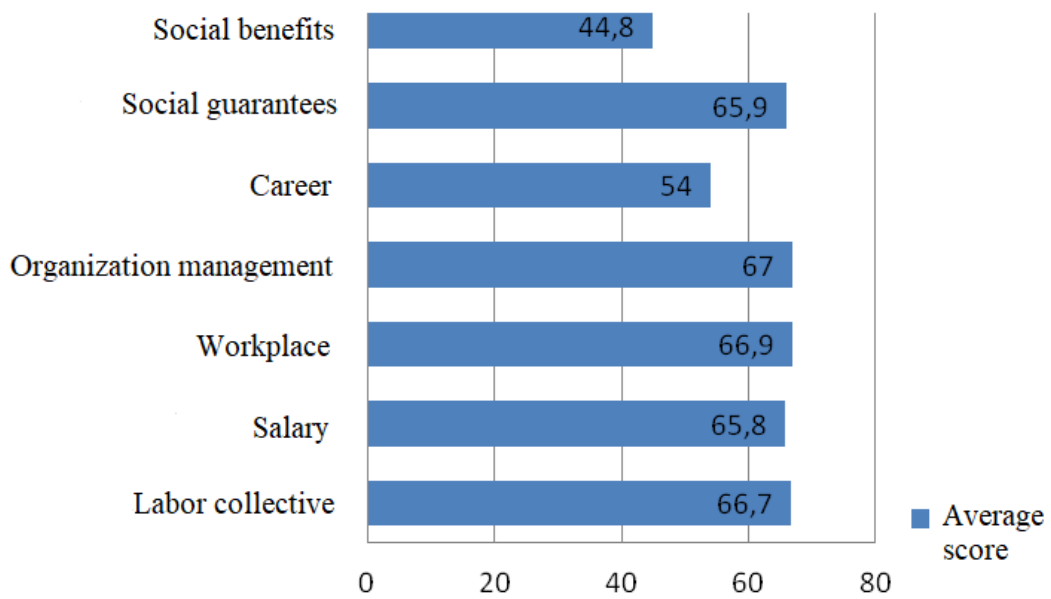

Fig. 2. Results of the questionnaire "Quality of working life" at enterprises of the Tyumen region

The results of the conducted research showed that workers of enterprises of the Tyumen region are generally satisfied with the quality of working life (but the values are not so high). This suggests that workers are not comfortable working at the surveyed enterprises.

Values calculated for the group "Labor collective" indicate a fairly comfortable psychological climate. Workers are satisfied with the social structure of the team and the efficiency of colleagues. There is no contradiction with the administration and regulatory documents are observed.

According to the group "Salary", workers consider the wage system to be justified, however, the wage rate could be higher. At most surveyed enterprises, there are various types of surcharges (for combining professions, remuneration for the final result, bonuses) and workers are generally satisfied with their size.

The results obtained in the group "Workplace" indicate a satisfactory working environment, equipment and ergonomics of the workplace, many enterprises have official transport. Employees are satisfied with the level of rationing and generally feel personal safety. 
The calculations made in the group "Management of the organization" indicate a trust in the management, however, at most enterprises there is no possibility of electing managers.

Employees of enterprises have lowly assessed the group of indicators "Professional Career": the employees of the surveyed organizations have virtually no career opportunities, but there exists encouraging employees to study and they consider objective attestation conducted at enterprises.

"Social guarantees", which are provided for by the legislation of the Russian Federation, are being implemented at the enterprises under study (there are no violations in the field of legislation by the employer). The lowest figure in this group is life and natural disasters insurance. In general, employees feel socially protected.

When calculating the results, indicators with a very low score were identified. These include virtually all indicators of the group "Social benefits" (the assessment is unsatisfactory): payment of material assistance for vacation; obtaining branded clothes and shoes; payment for sports and health services; gifts for birthdays and anniversaries; preferential loans for housing and car purchase; compensation of transportation costs; compensation of expenses for food; payment of expenses for children's institutions; achievement of full material well-being; sense of social well-being.

This suggests that practically every surveyed enterprise can be recommended to develop measures for any indicator from the group "Social benefits". This will greatly increase the value of the indicator of satisfaction with the quality of working life of workers, will be an incentive for productive work and ultimately will increase the economic performance of the enterprise.

In general, the average overall score for the surveyed enterprises of the Tyumen region is 413.8 points, which confirms a satisfactory assessment of the quality of working life of employees of these enterprises.

The conducted researches prove that there is no effective system of motivation and stimulation of workers at the present time in the modern enterprises of the Tyumen region. Employees of enterprises are not satisfied with the quality of their working life. This negatively affects the activities of enterprises, their productivity, profitability. An effective human resources management system should be built on a set of measures that include moral and material incentives.

It is possible to influence (manage) such parameters of the quality of working life, which are presented in Figure 3 [20]:

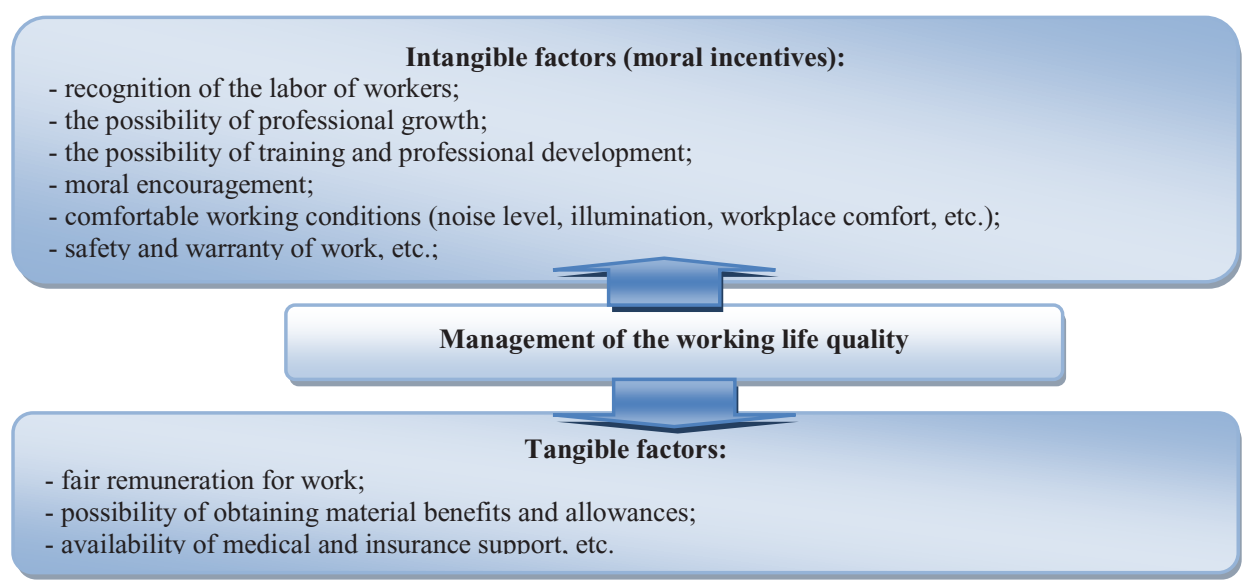

Fig. 3. Management of the working life quality.

Figure 2 demonstrates that moral stimulation is represented by a rather large list. The study shows, these indicators are very important for employees of enterprises. 
At the present stage of development, it is important not only to attract and retain staff in the organization, but also to properly stimulate it to work effectively. Responsible, effectively motivated, efficient personnel will increase the welfare of the enterprise; bring it to the category of competitive.

\section{Discussion}

In the course of the study of the working life quality in the enterprises of the Tyumen region and on the basis of the literature studied, it made it possible to identify the main directions of motivation of the human resources management system at the present stage of economic development.

To date, such "motivators" as "social goods" are practically not used. Employees of enterprises found this group of indicators very important in assessing the quality of working life.

An important aspect is the time indicator. Each period of time is characterized by a certain state of the economy as a whole and the level of quality of workers' working life. The results of the research showed that at this stage the employees are rather satisfied with such material indicator as the level of wages (however, many workers would like to have a larger salary). Although, according to some authors [10], wages in the management of human resources perform an important motivational function.

The state impact on the quality of life of the population as a whole is of great importance. To date, the priority areas of the social policy of the Russian Federation have been established [15], which include:

improving the welfare of citizens and reducing poverty;

modernization and development of the social services sector;

ensuring the availability of high quality social services for all the elderly and disabled people in need;

development of the sector of non-governmental non-profit organizations in the provision of social services;

improving the system of providing state and municipal services to citizens and organizations.

By raising the indicator of the quality of life of the population, the state contributes to the satisfaction of the population and the growth of the quality of working life of workers of individual enterprises. A person is not only a consumer of social goods, but also a carrier of certain knowledge, skills necessary for organizations and the state as a whole.

In our opinion, the methodology used has its drawbacks: orientation is mainly on material needs, while the range of interests of a person is extensive. Satisfaction of a person with the quality of working life is formed under the influence of a whole set of indicators and when favorable conditions are created.

\section{Conclusions}

Nowadays, the most important problem in the development of the economy of most countries is the problem in the area of work with personnel. Personnel are the main component of the human resources management system. The performance of an individual worker, and high performance of the organization depends on the satisfaction with work. And this, in turn, can be achieved by improving the quality of working life of workers.

The topic of the study is interesting for a number of reasons:

- it is important to take into account the time factor in the context of the level of development of the country's economy as a whole; 
- Indicators of evaluation the quality of working life offered by scientists are diverse and there is no unity of opinion.

In their work, the authors assessed the quality of working life of workers in the enterprises of the Tyumen region at the present time (at the present stage of economic development), which made it possible to identify those problematic indicators that managers of enterprises should pay special attention to and develop measures.

\section{References}

1. M. Gravit, O. Zybina, A. Vaititckii, A. Kopytova, Advances in Intelligent Systems and Computing 692, 1093-1101 (2018) DOI: 10.1007/978-3-319-70987-1_118

2. N. Zotkina, M. Gusarova, A. Kopytova, Advances in Intelligent Systems and Computing 692, 1204-1213 (2018) DOI: 10.1007/978-3-319-70987-1_129

3. A. Kopytova, Procedia Engineering 165, 1132 (2016) DOI: 10.1016/j.proeng.2016.11.830

4. A. Kopytova, MATEC Web of Conferences 106, 08056 (2017) DOI: 10.1051/matecconf/201710608056

5. N. Zotkina, S. Bardasov, M. Gusarova, A. Kopytova, MATEC Web of Conferences 106, 08050 (2017) DOI: 10.1051/matecconf/201710608050

6. K. Pykhtin, T. Simankina, V. Sharmanov, A. Kopytova, IOP Conference Series: Earth and Environmental Science 90(1), 012065 (2017) DOI: 10.1088/17551315/90/1/012065

7. V. Lezier, M. Gusarova, A. Kopytova, IOP Conference Series: Earth and Environmental Science 90 (1), 012034 (2017) DOI: 10.1088/1755-1315/90/1/012034

8. A. Minnullina, R. Abdrazakov, IOP Conference Series: Earth and Environmental Science 90 (1), 012089 (2017) DOI: 10.1088/1755-1315/90/1/012089

9. A. Minnullina, R. Abdrazakov, Advances in Intelligent Systems and Computing 692, 1224-1233 (2018) DOI: 10.1007/978-3-319-70987-1_131

10. A.V. Kopytova, Exchange of intellectual property 3 (XIV), 31-37 (2015)

11. V. Lezier, M. Gusarova, A. Kopytova, IOP Conference Series: Earth and Environmental Science 90 (1), 012069 (2017) DOI: 10.1088/1755-1315/90/1/012069

12. A. Mottaeva, A. Minnullina, IOP Conference Series: Earth and Environmental Science, 90 (1), 012123 (2017) DOI: 10.1088/1755-1315/90/1/012123

13. M. Gravit, O. Zybina, A. Vaititckii, A. Kopytova, IOP Conference Series: Earth and Environmental Science 90 (1), 012103 (2017) DOI: 10.1088/1755-1315/90/1/012103

14. N. Zotkina, A. Kopytova, M. Zenkina, O. Zhigunova, MATEC Web of Conferences 106, 08058 (2017) DOI: 10.1051/matecconf/201710608058

15. A. Minnullina, MATEC Web of Conferences 106, 08067 (2017) DOI: $10.1051 /$ matecconf $/ 201710608067$

16. A. Kopytova, E. Matys, N. Zotkina, I. Reshetnikova, N. Meller, I. Nekrasova, E3S Web of Conferences 33, 03053 (2018) DOI: 10.1051/e3sconf/20183303053

17. M. Fedorov, E. Matys, A. Kopytova, E3S Web of Conferences 33, 03054 (2018) DOI: $10.1051 / \mathrm{e} 3$ sconf/20183303054

18. A. Minnullina, V. Vasiliev, E3S Web of Conferences 33, 03060 (2018) DOI: $10.1051 / \mathrm{e} 3$ sconf $/ 20183303060$ 
19. M.S. Gusarova, Bulletin of Omsk University. Series: The Economy, 3, 111-119 (2012)

20. O.I. Frolova, International Scientific and Research Journal, 09 (51), 90-94 (2016)

21. A.V. Kopytova, Actual problems of economics and management, 1 (05), 34-41 (2015)

22. N.S. Zotkina, A.V. Kopytova, Competitiveness in the global world: economy, science, technology 6, 101-106 (2016)

23. A.V. Kopytova, Intellectual Property Exchange (BIS) 3(T. XIV), 31-37 (2015)

24. I. Zaychenko, S. Gutman, O. Kalinina Advances in Intelligent Systems and Computing, 692, 453-462 (2018) DOi - 10.1007/978-3-319-70987-1_48

25. I. V. Ilin, A.I. Levina, O. Iliashenko MATEC Web of Conferences, 86, (2016) 05028 DOi - 10.1051/matecconf/20168605028

26. I. V. Ilin, A. Lepekhin, A.I. Levina, O Yu. Iliashenko, Advances in Intelligent Systems and Computing, 692, 1306-1314 (2018) DOi -10.1007/978-3-319-70987-1_138

27. I. V. Ilin, A.I. Levina, O Yu. Iliashenko, MATEC Web of Conferences, 106, 08066 (2017) DOi-10.1051/matecconf/201710608066

28. V. V. Gluhov, I. V. Ilin, Lecture Notes in Computer Science, 8638, 509- 518 (2014) DOi-10.1007/978-3-319-10353-2_46 